\title{
GANGLION OF THE LATERAL POPLITEAL NERVE
}

\author{
Kenneth Clark, Stoke-on-Trent, England \\ From the Roval Infirmary, Edinburgh, Scotland
}

Cysts containing mucoid material and involving the lateral popliteal nerve as it lies in relation to the head of the fibula have been described on at least twelve occasions. The exact nature of the lesion has not been established.

Sultan (1921) reported the case of a patient with partial paralysis of the left lateral popliteal nerve due to cystic change. Treatment was by incision and evacuation of the contents of the cyst. A further case of partial paralysis from the same condition was reported by Zaar (1926). In two cases reported by Wadstein (1931) the cystic lesion had produced complete paralysis in the distribution of the anterior tibial nerve. In his first case the ganglion recurred after curettage and had to be dissected from the nerve; the second patient was treated initially by dissection and excision, partial recovery of function being obtained. The two cases reported by Ellis (1936) illustrated the relation of prognosis after operation to the duration of symptoms. In both cases symptoms had been present for one month, a rapid recovery of full function being obtained after the cyst had been emptied. A history of injury was given in one instance. Ferguson (1937) was able to dissect a bilocular cyst six centimetres long from the lateral popliteal nerve. Rapid recovery of function was obtained in twelve days; before operation there had been only slight weakness and paraesthesiae. He postulated mucinous degeneration of the connective tissue elements in the nerve as in ganglion. That complete paralysis can be produced in a short time was illustrated by Warren's (1946) case of complete paralysis after a history of only six weeks. A large multilocular cyst was resected and a graft inserted. Histological examination showed the lesion to be composed of connective and myxomatous tissue containing a cyst with a partial lining of synovial membrane. He ascribed the condition to a ganglion involving the connective tissue elements of the nerve.

Brooks (1952) described thirteen cases of nerve compression due to ganglion. In three cases the lateral popliteal nerve was compressed by a ganglion arising from the superior tibio-fibular joint. He suggested that ganglia of nerve sheaths and simple ganglia were anatomical variants of the same entity and considered that Sultan's case (1921) and Zaar's case (1926) were probably schwannomata. He refuted the suggestion that injury can produce the condition but stressed the importance of duration of compression in assessing the prognosis for recovery of function. Tupman (1957) reported a boy aged eighteen with sensory disturbance of six months' and drop foot of one month's duration; after surgical decompression of a large cystic swelling of the nerve complete motor and sensory recovery was obtained.

Ganglion of the lateral popliteal nerve, though rare, has thus evoked considerable discussion. Most authors have considered the condition to be one of simple ganglion involving the nerve and producing symptoms by compression of nerve fibres, though Jenkins (1952) included a similar type of case in his series of three neurilemmomata. There has been some doubt whether the ganglion developed in the nerve itself, as was suggested by Ferguson (1937), or arose from the superior tibio-fibular joint (Brooks 1952). The treatment most often recommended has been dissection of the cyst from the nerve. Simple evacuation of the cyst contents has once been followed by recurrence (Wadstein 1931). There are no reports available on the late results of treatment.

The present series comprises three cases of ganglion of the lateral popliteal nerve which have been under observation for over four years. Because all three cases were treated by resection of the involved area of nerve it has been possible to make a careful histological study in an attempt to establish the etiology of the condition. 


\section{CASE REPORTS}

Case 1-A male railway clerk aged forty-two was admitted in September 1950 with a twelve months' history of pain over the outer side of the right leg from knee to ankle. Three months after the onset of symptoms a tender swelling was observed over the head of the fibula; it gradually enlarged. On examination there was a tender firm swelling five centimetres long in the line of the lateral popliteal nerve extending distally from the head of the fibula, with complete paralysis of the tibialis anterior muscle and partial paralysis of the extensor hallucis longus and extensor digitorum longus muscles, the peronei being unaffected. Sensation was preserved. At operation in September 1950 six centimetres of the lateral popliteal nerve were excised and primary suture was performed. The nerve was found to be infiltrated by multiple cysts of various sizes. No connection with the superior tibio-fibular joint was seen. Histological examination confirmed the diagnosis of ganglion. The patient made good progress after operation, and two years later there was full power in the peroneal muscles, good power in extensor digitorum longus and slight return of function in the extensor hallucis longus. Five and a half years later, however, he reported with a four weeks' history of pain in the right leg associated with a tendency to drag his toes. A nodular swelling in the line of the lateral popliteal nerve extending for three centimetres distally from the head of the fibula suggested a recurrence of the original lesion. At operation (April 1958) no evidence of recurrence was found but there was considerable fibrosis around the nerve. Histological examination of the fibrous tissue excised showed no evidence of recurrence of the ganglia.

Case 2-A male brewery worker aged fifty-two was admitted in January 1952 with a two months' history of increasing pain radiating from the outer aspect of the left knee to the dorsum of the foot, numbness of the leg and foot and an increasing tendency to drag the left foot. Three weeks before the onset of symptoms he had struck the back of his knee on a metal tap. Examination revealed a tender swelling four centimetres long and one centimetre across involving the lateral popliteal nerve at the level of the neck of the fibula. There was complete reaction of degeneration in the muscles supplied by this nerve and complete loss of sensation in its cutaneous distribution.

At operation in January 1952 the lateral popliteal nerve was found to be infiltrated by multiple cysts. A five-centimetre length was resected and the gap was closed by primary suture. The diagnosis of ganglion was confirmed by histological examination. The patient's progress was good and when he was seen in February 1958 he had full recovery of sensibility, and motor recovery as follows: peronei, 5 ; tibialis anterior, 3 ; extensor digitorum longus, 4 ; extensor hallucis longus, 0 .

Case 3-A miner aged forty-two was admitted in October 1953 with a seven months' history of increasingly severe pain and paraesthesiae radiating from the outer side of the right knee to the foot. Foot drop had been noticed over the past five months. The patient spent most of his working day in the kneeling position, his left knee being protected by a pad retained by straps, one of which passed across the region of the head of the fibula. Two months before the onset of symptoms he had sustained a fracture-dislocation of the opposite knee. On examination there was a tender swelling fifteen by one and a half centimetres in the line of the lateral popliteal nerve distal to the head of the fibula. There was weakness of dorsiflexion and eversion of the foot and analgesia to pinprick in the lateral popliteal distribution. At operation in October 1953 the lateral popliteal nerve was found to be distended by multiple tense cysts over a distance of fourteen centimetres from the head of the fibula (Fig. 1). There was no connection with the superior tibio-fibular joint. The affected length of the nerve was resected, no repair being attempted. The diagnosis of ganglionic degeneration was confirmed histologically though a detailed serial section examination was not made because the specimen was preserved for exhibition. Follow-up examination in February 1958 revealed no evidence of recurrence.

VOL. $43 \mathrm{~B}$, NO. 4, NOVEMBER 1961 
TABLE I

Findings in Recorded Cases of Ganglion of the lateral Popliteal Nerve

\begin{tabular}{|c|c|c|c|c|c|c|}
\hline Author & Sex & $\begin{array}{c}\text { Age } \\
\text { (years) }\end{array}$ & $\begin{array}{l}\text { History } \\
\text { of } \\
\text { injury }\end{array}$ & $\begin{array}{c}\text { Duration of } \\
\text { symptoms } \\
\text { (months) }\end{array}$ & $\begin{array}{l}\text { Severity } \\
\text { of } \\
\text { paralysis }\end{array}$ & Operative findings \\
\hline Sultan (1920) & $\mathbf{M}$ & 56 & Nil & Few & Partial & $\begin{array}{l}3 \text { centimetres of cystic change } \\
\text { in nerve }\end{array}$ \\
\hline Zaar (1926) & $\mathbf{M}$ & 22 & Nil & 2 & $\begin{array}{c}\text { Complete } \\
\text { (motor and sensory) }\end{array}$ & $\begin{array}{c}6.2 \text { centimetre cyst in the } \\
\text { perineurium }\end{array}$ \\
\hline \multirow[t]{2}{*}{ Wadstein (1931) } & $\mathbf{M}$ & 36 & $\begin{array}{l}\text { Direct } \\
\text { injury }\end{array}$ & 8 & Complete & $\begin{array}{l}\text { Multiple cysts from gluteal fold } \\
\text { to neck of fibula }\end{array}$ \\
\hline & $\mathbf{M}$ & 48 & Nil & 1 & Complete & Cyst of size of little finger \\
\hline \multirow{2}{*}{ Ellis (1936) } & $\mathbf{M}$ & 13 & Nil & 1 & Complete & Multiple cysts \\
\hline & $\mathbf{M}$ & 44 & $\begin{array}{l}\text { Recurrent } \\
\text { at work }\end{array}$ & 1 & $\begin{array}{l}\text { Complete motor, } \\
\text { incomplete sensory }\end{array}$ & Single cyst \\
\hline Ferguson (1937) & $\mathbf{M}$ & 15 & Nil & $\frac{1}{2}$ & Incomplete & 6 centimetre trilocular cyst \\
\hline Warren (1946) & $\mathbf{M}$ & 29 & Nil & $1 \frac{1}{2}$ & Complete & $\begin{array}{l}6 \text { centimetre multilocular cyst } \\
\text { attached to superior } \\
\text { tibio-fibular joint }\end{array}$ \\
\hline \multirow{3}{*}{ Brooks (1952) } & $\mathbf{M}$ & 53 & Nil & 1 & $\begin{array}{c}\text { Partial } \\
\text { (motor and sensory) }\end{array}$ & $\begin{array}{l}\text { Unilocular cyst with attachment } \\
\text { to superior tibio-fibular joint }\end{array}$ \\
\hline & F & 67 & Nil & 48 & Complete & $\begin{array}{l}\text { Single cyst with attachment to } \\
\text { superior tibio-fibular joint }\end{array}$ \\
\hline & $\mathbf{M}$ & 44 & Nil & 72 & $\begin{array}{l}\text { Partial motor, } \\
\text { complete sensory }\end{array}$ & $\begin{array}{l}10 \text { centimetres of } \\
\text { cystic change }\end{array}$ \\
\hline Tupman (1957) & $\mathrm{F}$ & 18 & Nil & 6 & Complete & Single large cyst \\
\hline \multirow{3}{*}{ Present series } & $\mathbf{M}$ & 52 & $\begin{array}{l}\text { Direct } \\
\text { injury }\end{array}$ & 2 & Complete & 4 centimetre multiple cysts \\
\hline & $\mathbf{M}$ & 42 & $\begin{array}{l}\text { Recurrent } \\
\text { at work }\end{array}$ & 7 & $\begin{array}{c}\text { Partial } \\
\text { (motor and sensory) }\end{array}$ & 14 centimetre multiple cysts \\
\hline & $\mathbf{M}$ & 42 & Nil & 12 & Partial motor only & 6 centimetre multiple cysts \\
\hline
\end{tabular}

HISTOLOGICAL STUDIES

A serial section study has been made of two of the ganglia, the sections being stained by Mallory's trichrome stain and by haematoxylin and eosin.

Case 1-The cyst wall is composed of fibrous tissue with considerable degeneration of the intercellular substance which is greater towards the inner aspect of the cyst wall (Fig. 2). Two nerve bundles seen in the cyst wall can be traced throughout the full length of the specimen. An apparent lining membrane of the cyst (Fig. 3) is made up of degenerate fibroblasts. There is a noticeable increase in the number of nuclei towards the centre of the cyst, probably from loss of degenerate cytoplasm into the cavity of the cyst.

Case 2-The wall of the cyst contains much collagen. Towards the inner lining of the cyst the fibroblasts swell, their cytoplasm becomes basophilic and their nuclei undergo pyknosis and fragmentation. The cyst content is a homogeneous faintly basophilic material which has the appearance of mucin though it does not take up mucicarmine.

The histological picture described in these cases is like that of simple ganglion arising in relation to tendon sheaths and joint capsules. Nuclear proliferation or accumulation was described by Ogilvie (1948) as typical of simple ganglion. 
TABLE I-continued

Findings in Recorded Cases of Ganglion of the lateral Popliteal Nerve

\begin{tabular}{|c|c|c|c|}
\hline Histology & Treatment & $\begin{array}{l}\text { Duration of } \\
\text { follow-up } \\
\text { (months) }\end{array}$ & Result \\
\hline- & $\begin{array}{l}\text { Incision and evacuation } \\
\text { of contents }\end{array}$ & - & - \\
\hline Cyst without endothelial lining & Dissection excision & - & - \\
\hline Connective tissue rich in cells & Dissection excision & 36 & $\begin{array}{l}\text { No motor recovery. } \\
\text { Complete sensory recovery }\end{array}$ \\
\hline Connective tissue like synovial tissue & Dissection excision & 12 & Complete recovery \\
\hline- & Incision & 11 & Complete recovery \\
\hline Fibrous tissue lining of cyst & Incision & 3 & Complete recovery \\
\hline Mucoid degeneration as in ganglion & Dissection excision & 6 & Complete recovery \\
\hline $\begin{array}{l}\text { Myxomatous degeneration of } \\
\text { fibrous tissue. } \\
\text { Partial lining of synovial membrane }\end{array}$ & Dissection excision & - & - \\
\hline- & Dissection excision & 6 & Complete recovery \\
\hline Ganglion & Dissection excision & 3 & $\begin{array}{l}\text { Incomplete sensory recovery. } \\
\text { No motor recovery }\end{array}$ \\
\hline Ganglion & Dissection excision & 12 & $\begin{array}{l}\text { Complete sensory. } \\
\text { Incomplete motor }\end{array}$ \\
\hline Ganglion & Incision and evacuation & 6 & Complete recovery \\
\hline Ganglion & $\begin{array}{l}\text { Resection and primary } \\
\text { suture }\end{array}$ & 73 & $\begin{array}{l}\text { Complete sensory recovery. } \\
\text { Incomplete motor recovery }\end{array}$ \\
\hline Ganglion & Resection without repair & 52 & - \\
\hline Ganglion & $\begin{array}{l}\text { Resection and primary } \\
\text { suture }\end{array}$ & 91 & $\begin{array}{c}\text { Fibrosis requiring neurolysis } \\
\text { after } 8 \text { years }\end{array}$ \\
\hline
\end{tabular}

\section{DISCUSSION}

The findings in the recorded cases of ganglion of the lateral popliteal nerve are summarised in Table I, which is as complete as the published data allow.

The nature of the lesion-The condition is generally thought not to be a new growth, though Jenkins (1952) reported one case which he considered to be the result of cystic degeneration in a neurilemmoma. A histological study of the present cases has failed to reveal any evidence of the nuclear arrangement seen in that tumour, such as the palisading of Antoni type A tissue or the haphazard reticulation of Antoni type B tissue in which cystic degeneration may occur (Antoni 1920). The present study suggests that the cystic change is in the nature of a ganglion arising in the supportive or connective tissue of the nerve. The histological characteristics of fibroblastic proliferation with progressive cellular degeneration and mucoid accumulation are those seen in the more common type of ganglion which arises from a joint capsule or tendon sheath though no communication may be traceable between the cavity of the cyst and that of any adjacent tendon sheath or joint (Ogilvie 1948). No connection with the tibio-fibular joint (Brooks 1952) has been noted in the present series, a careful histological study revealing ganglionic degeneration of the supporting tissues within the nerve itself. There 
is little doubt that the interruption of nerve conduction is the result of compression of nerve fibres by the cyst formation, because the prognosis after excision or decompression is closely related to the duration of symptoms (Table I). Motor paralysis of more than two months' duration diminishes the possibility of full motor recovery.

The cause of the lesion-This remains in doubt, though a history of injury has been recorded in 25 per cent of the cases reported in the literature. A definite history of injury was given

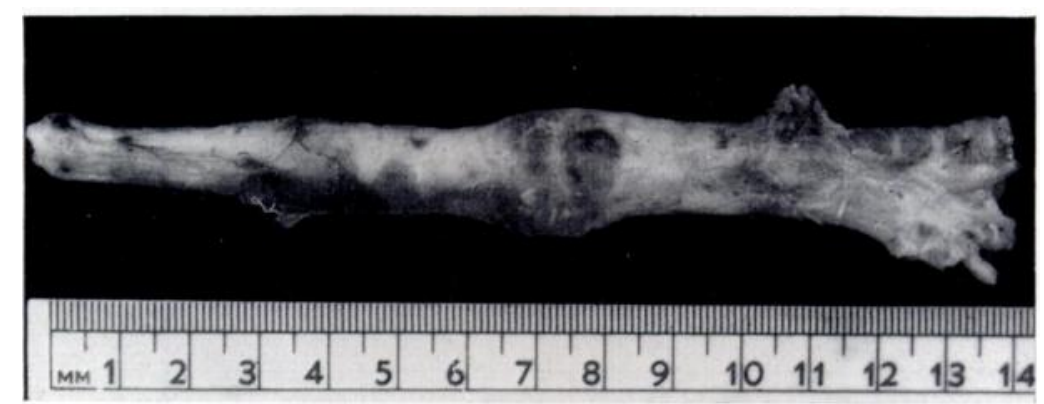

FIG. 1

Case 3-The length of nerve resected. Over twelve centimetres the nerve is distended by multiple cystic swellings lying within its substance.

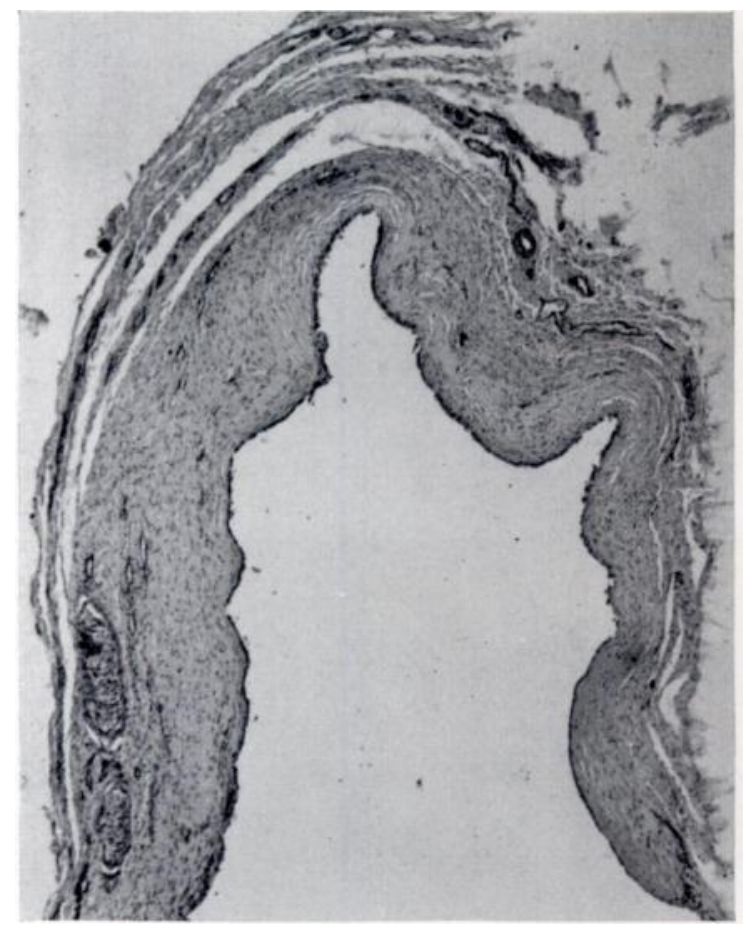

FIG. 2

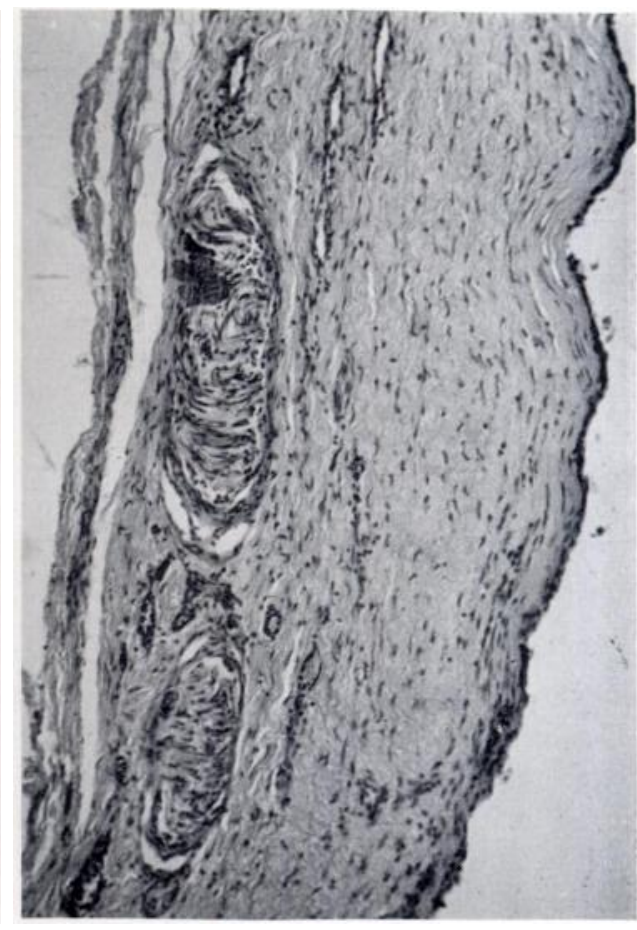

Fig. 3

Case 1. Figure 2-Transverse section of the cystic lesion, showing the fibrous nature of the cyst wall with its lining membrane. ( 40.) Figure 3-Magnified view of lower left hand part of previous section, showing the nerve bundles lying in the cyst wall. Marked fibroblastic degeneration is obvious in two foci towards the inner lining, which is composed of degenerate fibroblasts. $(\times 100$.)

in one of the three cases reported in the present series; chronic pressure by straps worn at work was noted in another. There seems little doubt that the lateral popliteal nerve in its subcutaneous position adjacent to bone is often exposed to compression and irritation. 
Treatment-This has varied considerably, as can be seen from Table I. Resection of the nerve was the procedure adopted in the cases here reported, because it was not thought possible to dissect the multiple cysts from the nerve fibres. As long as there is no evidence that the condition is a new growth the treatment should be that of dissection and enucleation when possible, and simple incision and expression of contents if dissection seems hazardous. Recurrence is possible after incision and expression (Wadstein 1931), but the recurrent cyst may be less extensive than the primary and thus amenable to dissection and enucleation.

\section{SUMMARY}

1. Three cases of ganglion of the lateral popliteal nerve are reported, all of which were treated by resection of the nerve.

2. In none was a connection between the ganglion and the superior tibio-fibular joint seen.

3. A careful histological study suggests that the condition is one of simple ganglion arising in the supporting tissues of the nerve.

4. A search of the literature has revealed twelve reported cases. The clinical and operative findings, together with the results of treatment, have been reviewed.

5. The treatment of choice is dissection of the ganglion from the nerve. If this proves difficult because of the multiplicity of cysts, incision and evacuation of cyst contents should be performed, although recurrence is possible after this procedure.

6. The prognosis for recovery of function is good when paralysis has been present for less than one year. Recovery of motor function is unlikely to be complete if there has been a longer duration of paralysis, though sensory recovery is usually good.

I wish to thank Sir Walter Mercer for permission to publish the cases reported in this paper. I am also indebted to Dr E. Isaacson, North Staffordshire Royal Infirmary, for his helpful criticism.

\section{REFERENCES}

ANTONI, N. R. E. (1920): Ueber Rückenmarkstumoren und Neurofibrome. München: J. F. Bergmann.

Brooks, D. M. (1952): Nerve Compression by Simple Ganglia. Journal of Bone and Joint Surgery, 34-B, 391.

Ellis, V. H. (1936): Two Cases of Ganglia in the Sheath of the Peroneal Nerve. British Journal of Surgery, 24, 141.

Ferguson, L. K. (1937): Ganglion of the Peroneal Nerve. Annals of Surgery, 106, 313.

Jenkins, S. A. (1952): Solitary Tumours of Peripheral Nerve Trunks. Journal of Bone and Joint Surgery, 34-B, 401.

Ogilvie, R. F. (1948): Pathological Histology. Third edition, p. 426. Edinburgh: E. and S. Livingstone Ltd.

Sultan, C. (1921): Ganglion der Nervenscheide des Nervus peroneus. Zentralblatt für Chirurgie, 48, 963.

Tupman, G. S. (1957): Axonotmesis of Anterior Tibial Branch of Lateral Popliteal Nerve Due to Ganglion of the Nerve-sheath. British Journal of Surgery, 45, 23.

Wadstein, T. (1931): Two Cases of Ganglia in the Sheath of the Peroneal Nerve. Acta Orthopaedica Scandinavica, 2, 221.

Warren, R. (1946): Ganglion of the Common Peroneal Nerve. Annals of Surgery, 124, 152.

ZAAR (1926): Uber Ganglien in der Nervenscheide. Zentralblatt für Chirurgie, 53, 2,551. 